\title{
An Ancestral Caddo Site on Mill Creek in Rusk County, Texas
}

Timothy K. Perttula

Heritage Research Center, Stephen F. Austin State University

Follow this and additional works at: https://scholarworks.sfasu.edu/ita

Part of the American Material Culture Commons, Archaeological Anthropology Commons, Environmental Studies Commons, Other American Studies Commons, Other Arts and Humanities Commons, Other History of Art, Architecture, and Archaeology Commons, and the United States History Commons

Tell us how this article helped you.

This Article is brought to you for free and open access by the Center for Regional Heritage Research at SFA ScholarWorks. It has been accepted for inclusion in Index of Texas Archaeology: Open Access Gray Literature from the Lone Star State by an authorized editor of SFA ScholarWorks. For more information, please contact cdsscholarworks@sfasu.edu. 


\section{An Ancestral Caddo Site on Mill Creek in Rusk County, Texas}

Creative Commons License

(c) (i) (8)

This work is licensed under a Creative Commons Attribution-NonCommercial 4.0 International License 


\title{
An Ancestral Caddo Site on Mill Creek in Rusk County, Texas
}

\author{
Timothy K. Perttula
}

\section{INTRODUCTION}

Site RC-15 (the $15^{\text {th }}$ site recorded in Rusk County by Jones) in Rusk County, Texas, in the Pineywoods, was identified by Buddy Calvin Jones during his wide-ranging survey investigations in East Texas in the 1950s-1960s. This ancestral Caddo site is on Mill Creek, a tributary stream in the mid-Sabine River basin (Figure 1), a few miles south of its confluence with Tiawichi Creek. The Oak Hill Village site (41RK214), a large ancestral Caddo settlement that was occupied between ca. A.D. 1150-1450 (Rogers and Perttula 2004; Perttula and Rogers 2007), is on Mill Creek not far south of Site RC-15.

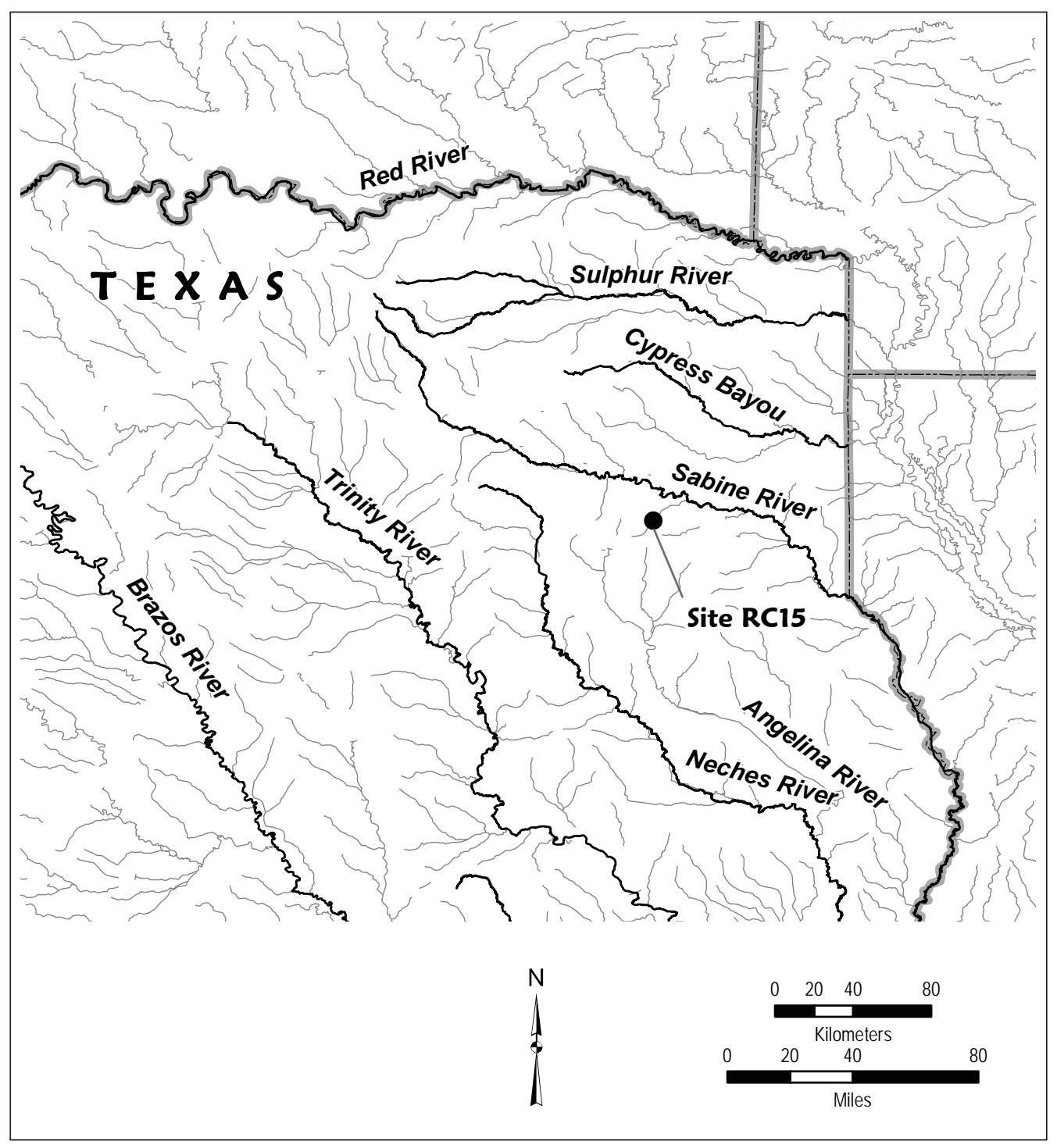

Figure 1. Location of Site RC-15 in East Texas. 


\section{Ceramic Sherd Assemblage}

Jones collected a sample of plain and decorated Caddo ceramic vessel sherds from RC-15. These sherds are in the collections of the Gregg County Historical Museum. About 82 percent of the collected sherds are from grogtempered vessels, and the remainder (primarily from utility ware vessels) have burned bone temper (Table 1).

Table 1. Ceramic sherd assemblage from RC-15.

\begin{tabular}{lccc}
\hline Ware & Grog-tempered & Bone-tempered & N \\
\hline Plain & 5 & - & 5 \\
Utility & 61 & 16 & 77 \\
Fine & 15 & 2 & 17 \\
\hline Totals & 81 & 18 & 99 \\
\hline
\end{tabular}

The 94 decorated sherds in the collection from RC-15 are from both utility ware vessels ( 81.9 percent) and fine ware vessels (18.1 percent). Among the utility ware sherds, incised (35.3 percent of all the decorated sherds) and punctated (35.3 percent) decorative methods/elements are prevalent, with low frequencies of appliqued-punctated (1.0 percent), brushed (1.0 percent), brushed-punctated (1.0 percent), and incisedpunctated (4.0 percent) vessel sherds (Table 2). The proportions of the different decorative methodsparticularly the comparable amounts of both incised and punctated sherds, and low amounts of incisedpunctated sherds - in the utility wares are consistent with the earliest (Group IV), estimated to date before ca. A.D. 1150, ceramic assemblage group at the Oak Hill Village site (Rogers and Perttula 2004:257 and Table 68). Group IV sites in a seriation of Caddo ceramic assemblages in the middle Sabine River basin have these proportions of utility wares: appliqued, 0.0-0.5 percent; brushed, 0.0-4.0 percent; incised, 33.3-44.3 percent; incised-punctated, 6.9-16.7 percent; and punctated, 26.7-40.6 percent.

Table 2. Decorative methods and decorative elements in the utility ware sherds from Site RC-15.

Decorative method/ Rim Body

Decorative element

Appliqued-Punctated

straight appliqued ridge and fingernail punctated row

Brushed

parallel brushing marks

Brushed-Punctated

horizontal brushed; tool punctated row below the lip

Incised

cross-hatched lines

curvilinear lines

diagonal lines

diagonal opposed lines

opposed lines

parallel lines

straight line

vertical lines
$-$

Rim Body

$\mathrm{N}$

1

$\begin{array}{lll}- & 3 & 3\end{array}$

$\begin{array}{lll}- & 3 & 3\end{array}$

3

1

- 3

$\begin{array}{ll}- & 11\end{array}$

$\begin{array}{ll}- & 5\end{array}$

\section{Incised-Punctated}

incised zones filled with tool punctations 
Table 2. Decorative methods and decorative elements in the utility ware sherds from Site RC-15, cont.

\begin{tabular}{llll}
\hline $\begin{array}{l}\text { Decorative method/ } \\
\text { Decorative element }\end{array}$ & Rim & Body & N \\
\hline Punctated & & 1 & 1 \\
circular punctated rows & - & 6 & 6 \\
fingernail punctated rows & - & 25 & 28 \\
tool punctated rows & 3 & 68 & 77 \\
\hline Totals & 9 & & \\
\hline
\end{tabular}

The sherds from incised vessels at the site feature straight and geometric elements, including Dunkin Incised vessels with diagonal and diagonal opposed incised lines (see Table 2); the cross-hatched incised sherds may also be from Dunkin Incised vessels (see Suhm and Jelks 1962:Plate 19i). The incised-punctated sherds from RC-15 have straight incised zones that have been filled with tool punctations, and may be from Pennington Punctated-Incised vessels (see Suhm and Jelks 1962:Plate 61). The many sherds with rows of punctations - circular, fingernail, and tool - are from undefined utility wares, although the fingernail punctated body sherds may be from the body of Kiam Incised vessels (see Suhm and Jelks 1962:Plate 45b-c, e).

The proportion of engraved sherds in the RC-15 assemblage (18.1 percent) is also consistent with Group IV ceramic assemblages in the middle Sabine River basin. The proportion of engraved sherds from sites in the ceramic assemblage seriation range from 11.1-17.1 percent (Rogers and Perttula 2004:Table 68).

The engraved sherds in the RC-15 assemblage include sherds from both bottles (11.8 percent) and carinated bowls (Table 3); one bottle sherd has had a red ochre-rich pigment rubbed in the engraved lines (Figure 2b). The rim sherds are from carinated bowls, and they included a rim from a Hickory Engraved vessel with horizontal lines, another with diagonal engraved lines (oriented left to right), a rim from a Holly Fine Engraved vessel with vertical and diagonal engraved lines, and another probable Holly Fine Engraved rim with vertical and curvilinear engraved lines (see Suhm and Jelks 1962:Plates 39f, h and 40b). The last of the engraved rim sherds has diagonal engraved lines as well as a zone of cross-hatching (Figure 2a).

Table 3. Decorative methods and decorative elements in the fine ware sherds from Site RC-15.

\begin{tabular}{llll}
\hline $\begin{array}{l}\text { Decorative method/ } \\
\text { Decorative element }\end{array}$ & Rim & Body & N \\
\hline $\begin{array}{l}\text { Engraved } \\
\text { cross-hatched zone* }\end{array}$ & - & 1 & 1 \\
curvilinear hatched zone* & - & 1 & 1 \\
diagonal lines & 1 & - & 1 \\
diagonal lines and cross-hatched zone & 1 & - & 1 \\
horizontal lines & 1 & 1 & 1 \\
horizontal and diagonal opposed lines & - & 3 & 3 \\
parallel lines & - & 5 & 1 \\
scroll fill zone element & - & - & 5 \\
straight line & - & - & 1 \\
vertical-curvilinear lines & 1 & 12 & 17 \\
vertical-diagonal lines & 1 & 5 & 17 \\
\hline Totals & 5 & & 1 \\
\hline
\end{tabular}

*Bottle sherds 


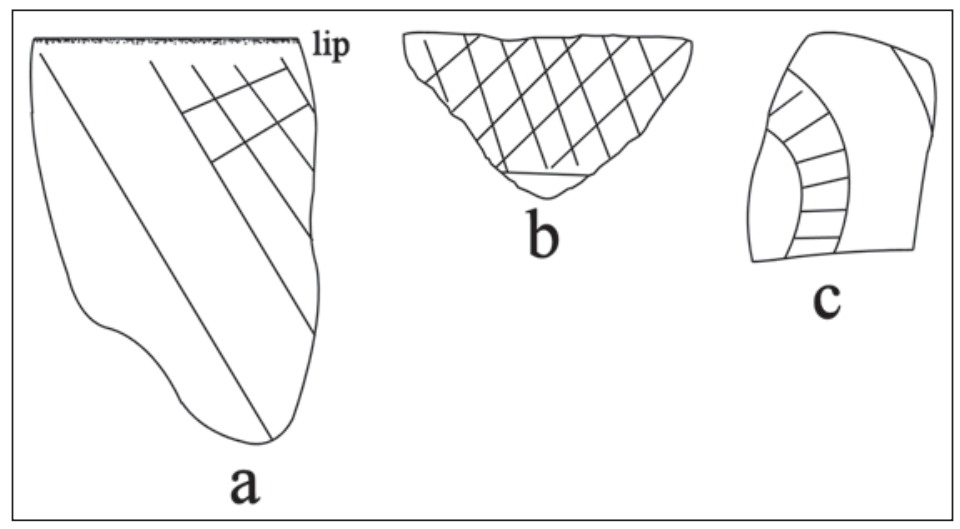

Figure 2. Selected decorative elements on engraved sherds from the RC-15 site in Rusk County, Texas: a, carinated bowl rim; b-c, bottle body sherds.

One of the bottle sherds has a horizontal engraved zone filled with cross-hatched engraved lines (see Figure 2b). This decorative element may be related to Engraved Decorative Element 27 defined in the Oak Hill Village ceramic assemblage (Rogers and Perttula 2004:Figure 91q). The other bottle sherd has a curvilinear engraved zone filled with hatching. This decorative element on one of the sherds at RC-15 is likely related to several common engraved decorative elements in the Oak Hill Village fine wares (Rogers and Perttula 2004:Figure 91b-f).

\section{SUMMARY AND CONCLUSIONS}

The RC-15 site is an ancestral Caddo settlement on Mill Creek in Rusk County, Texas, in the middle Sabine River basin. Buddy Calvin Jones identified the site and obtained a small collection of ceramic sherds from it, probably from the surface, and the collection is now at the Gregg County Historical Museum. The ceramic sherds are primarily from both grog-tempered and bone-tempered utility ware jars and fine ware carinated bowls and bottles. The proportions of the different decorative method classes in the assemblagefeaturing sherds with incised and punctated decorative elements - as well as the identification of sherds likely from Dunkin Incised, Kiam Incised, Pennington Punctated-Incised, Hickory Engraved, and Holly Fine Engraved vessels are consistent with pre-A.D. 1150 Caddo assemblages recognized at other sites in the middle Sabine River basin, including the Group IV assemblage from the Oak Hill Village site (41RK214) also on Mill Creek.

\section{ACKNOWLEDGMENTS}

Patti Haskins of the Gregg County Historical Museum provided access to the collections from the $\mathrm{RC}-15$ site, and that is greatly appreciated. Lance Trask prepared the figures in this article. 


\section{REFERENCES CITED}

Perttula, T. K. and R. Rogers

2007 The Evolution of a Caddo Community in Northeastern Texas: The Oak Hill Village Site (41RK214), Rusk County, Texas. American Antiquity 72(1):71-94.

Rogers, R. and T. K. Perttula

2004 The Oak Hill Village (41RK214), Rusk County, Texas. Document No. 030083. PBS\&J, Austin.

Suhm, D. A. and E. B. Jelks (editors)

1962 Handbook of Texas Archeology: Type Descriptions. Special Publication No. 1, Texas Archeological Society, and Bulletin No. 4, Texas Memorial Museum, Austin. Reprinted in 2009, Gustav's Library, Davenport, Iowa. 